\title{
ПОЛИТИЗАЦИЯ ЭКОЛОГИЧЕСКОГО ДИСКУРСА В АРХАНГЕЛЬСКОЙ ОБЛАСТИ НА ПРИМЕРЕ СТРОИТЕЛЬСТВА МУСОРНОГО ПОЛИГОНА ОКОЛО СТАНЦИИ ШИЕС
}

\begin{abstract}
Экологическая повестка заняла центральное место как в политической, так и в социальной формах протеста в России в 2018-2019 гг. Принятие решения об открытии мусорного полигона около станции Шиес в Архангельской области вызвало не только закономерное недовольство жителей политикой региональных элит, но и укрепило положение экологического протеста по всей России, прокладывая путь дискурсивному и фактическому политическому участию. Более того, кейс мусорного полигона около станции Шиес не является исключением, характеризующим российский контекст. Природа сегодня выступает не только объектом, но и субъектом политики во многих странах. Что позволяет сугубо социальному вопросу о состоянии окружающей среды и ее влиянии на повседневную жизнь людей приобретать черты политического обсуждения, требующего конкретного решения? Цель статьиопределить и показать механизмы политизации экологического дискурса в России на примере ситуации, связанной с открытием мусорного полигона около станции Шиес в Архангельской области. Мы покажем, как определенное политическое решение властей, принятое вне публич-
\end{abstract}

Кирилл Шамилевич Чмель- бакалавр политической науки, мл.н.с., Лаборатория сравнительных социальных исследований, Национальный исследовательский университет «Высшая школа экономики», Москва, Россия. Электронная почта: kchmel@hse.ru

Айгуль Маратовна Климова- к.с.н., доцент, Департамент социологии; ст.н.с., Лаборатория сравнительных социальных исследований, Национальный исследовательский университет «Высшая школа экономики», Москва, Россия. Электронная почта: amavletova@hse.ru

Евгения Михайловна Митрохина- аспирант школы политических наук, стажер-исследователь, Лаборатория сравнительных социальных исследований, Национальный исследовательский университет «Высшая школа экономики», Москва, Россия. Электронная почта: emitrokhina@hse.ru 
ного обсуждения и при игнорировании конкурирующих дискурсов, привело к доминантному дискурсивному конструированию экологической проблемы как политической. Эмпирической базой исследования послужили 19 полуструктурированных интервью с жителями Архангельской области. Методологией исследования выступает дискурс-анализ, в основе которого лежит аргументативная традиция. Мы сфокусируемся исключительно на аргументативных конструкциях - ссылках на факты, нормативно-правовые акты, риторических приемах для обоснования мнения,- которые субъекты используют для доказательства правоты своей позиции. Покажем, что политизация дискурса и высокая политическая мобилизация граждан произошли за счет трех основных механизмов, которые сработали одновременно: оценка принятого властями решения как нелегитимного, как несправедливого, а также выделение определенных политических лидеров в качестве ответственных за эту несправедливость.

Ключевые слова: экология, политизация, дискурс, мусорный полигон, Шиес DOI: $10.17323 / 727-0634-2020-18-1-83-98$

Экологический протест стал формой политического протеста в России в 2018-2019 гг. Так, в Архангельской области жители выступили против строительства мусорного полигона около железнодорожной станции Шиес, на территории которого планировалось размещать твердые бытовые отходы из Москвы и Московской области. Сокрытие информации о начале строительстве мусорного полигона и отсутствие публичного обсуждения строительства привели к высокой протестной активности жителей (см. ИА REGNUM 2019). По оценкам организаторов, на протестные акции в декабре 2018 г. по всей области вышли до 30 тыс. человек (Крючкова 2018).

В этом исследовании мы определяем и показываем механизмы политизации экологического дискурса на примере ситуации, связанной с открытием мусорного полигона около станции Шиес. Мы продемонстрируем, каким образом политическое решение властей, принятое вне публичного обсуждения и без учета конкурирующих дискурсов, привело к доминантному дискурсивному конструированию экологической проблемы как политической. Согласно выводам нашего исследования, политизация дискурса произошла за счет трех основных механизмов, которые сработали одновременно: (1) оценка принятого властями решения как нелегитимного, (2) интерпретация ситуации как несправедливой и (3) назначение определенных политических лидеров в качестве ответственных.

В отличие от предшествующих исследований, посвященных политическому поведению и дискурсивному политическому участию (Smyth et al. 2013), в этой работе мы исходим из других теоретических предпосылок, используя в качестве основы теории модернизации, ценностной трансформации и экологической справедливости вместо привычных 
предпосылок о политической культуре (Кертман 2000), культуре участия (Greene 2014) и эмоций в политике (Jasper 2018). Мы опираемся на экосоциологический подход Олега Яницкого (Яницкий 2011, 2009), где в том числе производство отходов называется «глобальной геополитической проблемой» (Яницкий 2017). Мы продолжаем ряд работ, посвященных исследованию экополитической мобилизации в российских регионах (Кулясов 2003; Воробьев 1999).

\section{Политизация экологического дискурса}

Природа перестала оставаться контекстом существования человечества, будучи инкорпорированной в политическую повестку через обсуждение вопросов экологии. Парламентарии отстаивают права не-людей в той же мере, в какой они представляют интересы граждан (Latour 2011: 72). Определение экологического дискурса само по себе не включает политический компонент. Базовыми единицами экологического дискурса являются объекты природы, которые создают основу для суждений о естественности равенства, толерантности и гармонии человека с природой (Dobson 2012:29). Именно эти понятия являются ядром любого экологического дискурса, политизация которого происходит, когда данные суждения начинают расцениваться с точки зрения морали и валидируются этикой (Stavrakakis 1997: 272). Иными словами, когда упомянутые выше суждения становятся предметом спора о морально верной и справедливой организации институтов, экологический дискурс политизируется.

Экология долгий период времени относилась к области «дискурса о глобальном», формирование которого стало следствием стремительной модернизации и преобладания негативных последствий технологического прогресса (Bell 1994), среди которых - климатическая катастрофа и загрязнение окружающей среды (см. Яницкий 2013). Для политических агентов издержки модернизации, ориентированной на темпы экономического развития, актуализировали необходимость однозначного выбора в дилемме «экономический рост - сохранение окружающей среды» и, как следствие, переход к модели устойчивого развития (Redclift 1987). Политические решения, принимаемые должностными лицами в сфере экологии, зачастую связаны с внутриполитическим контекстом, а не с абстрактными глобальными последствиями (Hajer 1995: 128).

Граждане также не остаются в стороне от обсуждения экологических проблем. В то время как лозунги экологических движений в США и Европе проблематизировали состояние экологии для спасения всего мира, т.е. как проблему западных демократий, капитализма или «глобального мира» в целом (см. Blühdorn, Welsh 2007), в России имеет место как глобальная постановка проблемы, так и черты исключительно локального дискурса. Теории модернизации связывают подобный интерес граждан и конструирование социаль- 
ной значимости экологического вопроса с рядом факторов. Посредством новых каналов коммуникации дистанцированные глобальные проблемы интегрированы в область личного опыта граждан, вызывая заинтересованность, стимулируя эмоциональную привязанность и чувство ответственности (Thompson 1995:251). Экологическая проблема все больше приобретает локализованный в личном опыте характер, а пути ее решения обнаруживают себя не только на уровне глобальных политических решений. Совмещение политической логики и социальной значимости вопроса делает экологический вопрос частью «политики жизни» (life politics), суть которой заключается в саморегулировании и индивидуальной мотивации (Giddens 1991). Такая индивидуализированная политика, направленная на защиту окружающей среды, начинается, например, когда гражданин принимает решение об отказе от товаров, использование которых потенциально вредит экологии.

Экологический дискурс характеризуется высокой фрагментацией, где монополией на принятие решений и оценку рисков не обладают единолично ни экологи, ни политики, ни журналисты. Это означает, что в процесс принятия политического решения относительно экологических проблем вовлекаются разные группы, в том числе граждане (Hajer 1995: 12). Отсюда следует, что экологический дискурс создает уникальную среду для принятия политических решений, а также новые пути его политизации на уровне конкурирующих дискурсов.

Основываясь на анализе литературы, мы подразделяем механизмы политизации экологического дискурса на три типа. Первый-через оспаривание легитимности принятых институциальных решений. Таковые в области экологической политики легитимируется через экспертные заключения и публичные обсуждения. Легитимация опосредуется общим доверием государству и доверием политикам и экспертам (Sjöberg 2001 a). В случае недоверия институтам или экспертам решения не признаются легитимными, что приводит к политизации дискурса. Второй механизм политизации - оценка справедливости данного решения. Политика в области экологии может быть описана с точки зрения перераспределения ресурсов, но вместе с благом ассиметричным образом перераспределяются и издержки (Walker 2012). Проблема перераспределения издержек наиболее остро проявляется, когда населению навязываются институциальные риски (Гидденс 1991). Третий механизм - каузальная атрибуция ответственности. Глобальные экологические риски порождают проблему «организованной безответственности» относительно последствий принятых решений (Бек 2000). Вместе с тем и индивиды, и институты участвуют в принятии решений, а значит, несут ответственность за риски (Дуглас 1994). Мы утверждаем и проверяем ниже на эмпирическом материале, что моральная оценка экологической ситуации в терминах легитимности, несправедливости и ответственности является основой политизации экологического дискурса. 


\section{Эмпирическая база и методология исследования}

Эмпирическая база состоит из 19 полуструктурированных интервью. Интервью собраны с помощью мессенеджеров и по телефону в феврале 2019 г. Для обеспечения анонимности респондентов информация представлена в сокращенном виде. Двенадцать интервью проведено с мужчинами, семь с женщинами. Возраст информантов варьировался от 18 до 67 лет. Интервью проведены с жителями семи населенных пунктов Архангельской области: семь респондентов из Архангельска, шесть из Северодвинска, два из Коряжмы и по одному респонденту из Котласа, Новодвинска, Урдомы и Яренска. Многие информанты распространяли информацию о строительстве мусорного полигона в социальной сети Вконтакте и принимали участие в протестных акциях. Для рекрутирования использована целевая выборка: изначально вход в поле осуществлен через сети знакомств исследователей и социальную сеть Вконтакте, где пост о поиске информантов был опубликован в ряде «пабликов» Архангельской области. Далее для рекрутирования новых информантов использовался метод снежного кома.

Методологической основой дискурс-анализа в этой работе является аргументативная традиция, получившая свое распространение на пике популярности теории делиберативной демократии Юргена Хабермаса (Хабермас 2010) и анализа публичной политики в работах Джона Драйзека (Dryzek 1993). Мы фокусируемся исключительно на аргументативных конструкциях - ссылках на факты, нормативно-правовые акты, на риторических приемах для обоснования собственного мнения,- которые используются для обоснования своей позиции (Cohen 1987).

Схема кодирования включала три основных кода: легитимация (доверие политикам, обсуждение проблемы в публичном дискурсе, обсуждение проблемы в региональных СМИ, наличие экспертиз); справедливость (процедурная и дистрибутивная, пояснения о которых будут представлены ниже) и атрибуция ответственности (региональные власти, федеральные, московские, президент). Два автора кодировали все интервью и сопоставляли результаты кодирования. В случае несогласия с кодированием исследователи обсуждали, какой из кодов является более релевантным.

\section{Результаты}

\section{Легитимация}

Легитимация является основой поддержания любого существующего политического порядка, посредством которой институты власти могут выражать политическую волю как коллективную и осуществлять ее. Информанты не признают легитимность принятия решения властями о строительстве мусорного полигона. Основная аргументация строится на претензии 
к региональным властям в связи с сокрытием факта строительства полигона. Обман жителей властями, отказ подтвердить информацию о строительстве полигона, когда уже были зафиксированы начавшиеся работы и опубликованы «посты» в социальных сетях, приводит к полной потере институциального доверия и дальнейшим сложностям в коммуникации между региональной властью и местным населением: «Люди больше недовольнь тем, что правды нет» (информант 1, Яренск).

Результаты эмпирических исследований показывают, что особенно остро риски от мусоросжигательных заводов или полигонов для хранения мусора воспринимает население, живущее непосредственно вблизи подобных предприятий (Lima 2004). Однако в случае Архангельской области протестная активность сосредоточилась в административном центре региона, находящемся в 500 км. от станции Шиес. Институциально навязанные риски, которые скрывались от населения, привели к увеличению политической вовлеченности жителей в местную повестку и жизнь региона. Респонденты не признают легитимность решения власти, аргументируя, что это «наша земля», а полигон- «московский» (информант 3, Архангельск). В попытке оправдаться власти подчеркивали сумму инвестиций в регион и безопасность европейских технологий хранения твердых отходов, называя полигон «Экотехнопарком». Однако притязания на значимость мусорного полигона для экономики региона не проходят валидацию в связи с тем, что притязания на истинность со стороны региональных властей не прошли проверку в самом начале: «Типа Экотехнопарк в кавычках, но все понимают, что у нас будет свалка» (информант 19, Северодвинск).

Жителям сложно просчитать современные экологические риски, поэтому легитимация решения строительства мусорного полигона может быть опосредована экспертными заключениями. Региональные власти не проводили экспертиз, согласно которым они могли бы показать результаты, хотя, по мнению информантов, с этого они должны были начать. В аргументативных конструкциях некоторые участники апеллируют к проведению экспертиз без коррупционных схем, согласно которым в случае их объективности должны быть показаны высокие риски: «Там болота, там истоки рек, это все будет загажено <...> Экологическая экспертиза, она во многом подтвердит» (информант 12, Архангельск). В своих аргументациях респонденты не ставят под сомнение возможность объективно полученных экспертиз и объективного экспертного знания о рисках, хотя большинство научных исследований показывает противоречивость результатов в оценке рисков (Sjöberg 2001 b). Информанты отмечают, что процедура экспертизы будет носить скорее формальный характер и покажет отсутствие рисков построения мусорного полигона под давлением властей: «Экспертиза, которая проведется, она будет положительная только потому, что вложень огромные деньги» (информант 1, Яренск). 
По словам информантов, большинство региональных медиа Архангельской области либо не освещали проблему строительства мусорного полигона, либо представляли точку зрения властей области. При этом со стороны респондентов есть запрос на более активную вовлеченность журналистов: «На журналистов надо надеяться, нужна всеобщая огласка» (информант 2, Котлас). Фреймирование строительства мусорного полигона как «Экотехнопарка», который приведет к привлечению больших инвестиций и западных технологий, обеспечивающих безопасность хранения, вызывает недовольство и недоверие со стороны респондентов: «Я так понимаю, они пытаются нас убедить, что помойка - это здорово» (информант 13, Новодвинск).

\section{Справедливость}

Говоря о справедливости как об инструменте политизации, необходимо разделять два уровня аргументации. Локальные сообщества, как правило, обращаются к дистрибутивной справедливости, то есть насколько само распределение издержек и преимуществ является честным. Информанты также апеллируют к процедурной справедливости, подразумевающей, что решения должны быть приняты в установленном институциальном порядке (Tyler 1994).

Аргументируя выбор именно Архангельской области для строительства, респонденты ссылаются не на социально-демографические показатели среды, а на особенности локального сообщества: «Депрессивный регион, отсталое развитие, большая область, гигантская, площади огромные» (информант 18, Архангельск). Одна из ключевых проблем дистрибутивной справедливости открытия мусорного полигона заключается в асимметричном характере распределения ресурсов. Из области «выкачивают» природные ресурсы, не компенсируя и получая вовсе отрицательное сальдо в результате перераспределения издержек: «Oт нас качают нефть, газ, тот же лес, те же алмазы, все идет от нас, а к нам инвестиции практические никакие не вкладываются, а еще сюда нам везут мусорку» (информант 1, Яренск). Ключевую роль начинает играть аргумент, связанный с истоками мусора. Исследования центр-региональных отношений в России традиционно подчеркивают структурную асимметрию. Согласно результатам опросов, большинство россиян считает, что в Москву стекаются материальные ресурсы со всей страны, и это является главной причиной негативного отношения (Виноградова 2019). Аналогичным образом, информанты признаются, что отрицательно относятся к открытию мусорного полигона не столько из-за рисков, сколько из-за источника привезенного мусора: «Эмочионально здесь вот в моем окружении, по крайней мере, люди воспринимают привоз из Москвы мусора не так опасно, [а] как оскорбление, как обиду» (информант 12, Архангельск).

Процедурная справедливость, напротив, не вызывает консенсуса у участников. Так, некоторые респонденты указывают, что принятое 
решение находится в области правового регулирования и соответствует законам РФ. В аргументации информанты ссылаются на отсутствие барьеров внутри страны для торговли и обмена ресурсами, говоря о наличии общего внутреннего рынка: «Если берём ту классную трактовку, что это товар, единство экономического пространства России. Ну, чего уж поделатьтакая Конституция, такие законыл» (информант 16, Архангельск). Для других респондентов принятие решения об открытии мусорного полигона является «грубым нарушением различных норм», а помимо всего прочего«нарушение очень серьёзное природоохранного законодательства» (информант 17, Архангельск). Отсюда наиболее сильным аргументом является именно нарушение природоохранного статуса территории, который упоминается практически всеми информантами. Респонденты упоминают здесь географические объекты (реки, болота), а также экосистему рек Архангельской области, загрязнение которой приведет к экологической катастрофе.

Однако оценивая процедурную справедливость, необходимо отбросить оценки последствий решений и говорить о честности самой процедуры (Ролз 2010: 86). Отсюда более близкой к политической проблематике является критика информантами таких процедурных аспектов, как представительство интересов, универсальность правового применения или соответствие законодательных актов их иерархии. Респонденты говорят, что принятое решение- «это нарушение конституционньхх прав, это 42 статья Конституции $1_{\Downarrow}$ (информант 1, Яренск). Один информант также указал на неуниверсальный характер правового применения. В то время как одни регионы, находясь в привилегированном положении, обладают правом на законодательный запрет ввоза мусора, другие регионы такой политической волей не обладают: «Bы знаете, что в Москве и Московской области такой закон действует? К вам запрещено ввозить мусор извне» (информант 10, Северодвинск).

Апелляция к справедливости закономерным образом порождает запрос к пересмотру решения властей об открытии мусорного полигона. В то время как одни требуют пересмотреть процедурный аспект, т.е. каким образом власти согласовали открытие мусорного полигона, другие требуют пересмотра данного решения с точки зрения дистрибутивной справедливости: «Люди-то ведь требуют внести законодательство по тому, что, например, не ввозить отходы с других регионов» (информант 4, Коряжма).

\section{Атрибуция ответственности}

Информанты не приводят сильных аргументов в процедурах каузальной атрибуции ответственности. Однако дискурс атрибуции ответственности является эмоционально нагруженным. Некоторые респонденты

\footnotetext{
${ }^{1}$ Статья 42 Конституции РФ: «Каждый имеет право на благоприятную окружающую среду, достоверную информацию о ее состоянии и на возмещение ущерба, причиненного его здоровью или имуществу экологическим правонарушением».
} 
говорят о вине власти, не конкретизируя определенных должностей или политиков, так как «все это представляется очень запутанным клубком интересов» (информант 8, Архангельск). Ряд исследователей подчеркивает сложность вменения ответственности определенным институтам и предприятиям за экологические риски (Бек 2000; Гидденс 1991). Некоторые информанты упоминают ответственность власти как нечто абстрактное. Провал воспринимается на уровне институциальной власти без разделения на региональную и федеральную, как провал, в котором виноваты «и те, и другие» (информант 19, Северодвинск).

Респонденты проводят разграничение не на основании полномочий властей, а на основании различения ответственности за принятие решения об открытии полигона и ответственности за последствия данного решения. В то время как ответственность за принятое решение ложится на Москву как центр федеральной власти, ответственность за последствия данного решения несет региональная власть и, в частности, губернатор области. «Москва» при этом представляется без четкого выделения институтов власти и без политических акторов, которые в глазах информантов репрезентируют федеральный центр: «Говорить Москве: "Вот, какой у нас нехороший губернатор",- нелепо, потому что губернатор у нас очень послушно выполняет эту московскую повестку» (информант 3, Архангельск).

Аргументативная конструкция строится на основе представлений о вертикали власти. Последняя, по мнению информантов, представляет собой структуру, где приказ о строительстве формируется сверху, а исполнением решения занимаются губернатор и региональные чиновники. Отсутствие обратной связи в институтах власти не предполагает корректировки принятых решений с учетом местного контекста. Представления о «Москве» как центре, который инициировал строительство мусорного полигона, достаточно абстрактны. Информанты не перечисляют институты власти и политиков, которые могут быть названы в качестве ответственных за принятие решения на федеральном уровне, однако именно на федеральном уровне главы государства, по мнению участников, может быть отменено или скорректировано решение.

Несмотря на то что решение инициировано Москвой, ответственность за него в том числе несет региональная власть, прежде всего, в лице губернатора. Информанты в качестве сравнения приводят другие регионы, в которых губернаторы смогли отказаться от строительства мусорных полигонов (Ярославская, Владимирская, Тверская и Вологодская области). Однако губернатор Архангельской области, по мнению респондентов, не защитил интересы жителей области, не противостоял вертикали власти, «дал слабинку» (информант 2, Котлас), не отстоял интересы области, и, возможно, участвовал в некоторых коррупционных схемах и сделках: «Bопросы, я думаю, тут только в деньгах» (информант 19, Северодвинск). Ответственность за последствия размещения полигона в Архангельской 
области полностью приписываются региональным властям. Данная оценка усиливается на фоне проблем с безработицей, бедностью, здравоохранением в регионе. Ответственность вменяется прежде всего губернатору области: «Лично губернатор Юрий Анатольевич. Это его рук, это его кулуарное решение» (информант 17, Архангельск).

Каузальная атрибуция ответственности усиливается за счет двух основных аргументативных конструкций. Во-первых, губернатор идентифицируется как чужак, «приезжий», «калининградец», который «до сих пор не получил архангельской прописки» (информант 1, Яренск) и который мало связан с Архангельской областью: «Он просто знает, что сейчас он здесь, завтра будет в другом месте, и что там после него останется, наверное, его это не заботит» (информант 1, Яренск). Во-вторых, каузальное приписывание ответственности усиливается сильной аффективностью в оценках экологических рисков и отрицательных последствий для области, когда утверждения основаны скорее на аффективной, чем когнтивной составляющей.

\section{Заключение}

Энтони Гидденс утверждает, что в обществе риска наступила новая эра морального климата для политики: любое политическое решение-это решение о рисках, их последствиях, их снижении или управлении (Giddens 1999). Coвременная политика- это арена борьбы между ценностями, которые представляют разные политические решения, а значит, разные риски. Политики должны понимать, что именно ответственность за риски является базисом политической арены, а это увеличивает ответственность политиков и делает запрос на обсуждение решений с гражданами более актуальным (Ibid). Мы показали, что принятие решения в области экологической политики в современной России может послужить триггером политизации дискурса и мобилизации населения. Так, мы обнаружили значимость трех основных механизмов в политизации экологического дискурса в Архангельской области: оспаривание легитимности решения, оценка его справедливости и атрибуция ответственности за принятое решение.

Легитимация позволяет представителям власти выразить коллективную волю без вовлечения граждан в политические решения, оставляя их лояльными государству (Хабермас 2010: 63). Но именно через публичную сферу посредством обсуждений и коммуникации с гражданами легитимируются решения государственных институтов. В связи с ограниченным функционированием публичной сферы в России (Каширских 2012) складывается впечатление об отсутствии запроса со стороны жителей на публичное обсуждение социально-политических проблем. Однако строительство полигона около станции Шиес свидетельствует об обратном. Информанты указывают на замалчивание планов о строительстве со сто- 
роны региональных властей, сокрытие информации со стороны СМИ, а также на отсутствие необходимых процедур и формальных экспертиз о безопасности строительства мусорного полигона. В связи с этим жители Архангельской области не признают легитимность решения о строительстве мусорного полигона.

Справедливость как аргументативная конструкция является значимым элементом повестки экологических движений, которая выводит проблематику защиты окружающей среды из области социальной в политическую (Bullard 1990). Именно справедливость конструирует фрейм коллективного действия посредством апелляции к неравномерному распределению рисков. Хотя в литературе подчеркивается роль процедурной справедливости в степени удовлетворенности политикой (Sunshine, Tyler 2003), доминирующей аргументативной конструкцией наших респондентов является именно дистрибутивная справедливость. Базовая аргументация респондентов основана на дискурсе о несправедливости размещения издержек от открытия мусорного полигона в Архангельской области. Менее явно респонденты апеллируют к процедурной справедливости. Вместе с тем аргументация о нелегитимности и несправедливости решения приводит участников к запросу о пересмотре правового регулирования строительства мусорного полигона около станции Шиес.

Зачастую четкая каузальная атрибуция ответственности за риски и последствия связана с мобилизацией и протестной активностью. Как правило, гражданам сложно определить виновных политических акторов в связи с тем, что проблема является размытой или не всегда интерпретируется именно в таких терминах. Кейс строительства мусорного полигона в Архангельской области является уникальным в связи с тем, что проблема ясна, наблюдаема, трактуется как проблема всеми участниками и имеет политические основания. Хотя информанты не выстраивают сильные аргументы в процедурах каузальной атрибуции ответственности (см. Сироткина, $\mathrm{Ce}$ менов 2019), обвинение региональных властей и, в частности, губернатора области усиливается за счет двух принципов. Принцип социальной категоризации, когда приписывание губернатора к аутгруппе усиливает его ответственность за навязанные риски и отрицательные последствия. И принцип аффективности восприятия рисков, который приводит к тому, что наиболее усиленно работает механизм атрибуции вины (Slovic et al. 2004).

В завершении укажем на два основных ограничения исследования. Во-первых, в связи с методом рекрутирования включенные в выборку информанты смещены в сторону более активных участников. Во-вторых, использован метод аудио-интервью, что ограничило погруженность исследователей в поле. Несмотря на данные ограничения, наше эмпирическое исследование показало, что недоверие к региональным властям, обвинения в их адрес и оценка сложившейся ситуации как несправедливой по отношению к региону и местным жителям привели к политизации экологического 
дискурса и, как следствие, к высокой мобилизации и протестной активности жителей Архангельской области.

\section{Выражения признательности}

Статья подготовлена при финансовой поддержке РФФИ и АНО ЭИСИ, грант № 19-011-31546 «Влияние современных коммуникативных технологий на формирование общественного мнения в новой медийной среде». Авторы выражают признательность студентам НИУ ВШЭ Дарье Барановой, Алине Лютиковой и Полине Малютиной за помощь в сборе пяти из 19 интервью, а также Никите Савину и участникам семинара НУГ НИУ ВШЭ «Нереактивные методы в коммуникационных исследованиях» за ценные комментарии к работе.

\section{Список источников}

Бек У. (2000) Общество риска: на пути к новому модерну. М.: Прогресс-Традиция.

Виноградова А. (2019) Совсем зажрались: кто в России не любит москвичей. Доступно по ссылке: https://www.gazeta.ru/lifestyle/style/2019/05/a_12385219.shtml (дата обращения: 5 июля 2019).

Воробьёв Д. (1999) Кампании по защите карельских лесов: мобилизация ресурсов. Е. Здравомыслова, М. Тысячнюк (ред.) Экологическое движение в России. Сб. научн. статей. СПб.: ЦНСИ: 72-87.

Гидденс Э. (1991) Судьба, риск и безопасность. Thesis, (5): 107-134.

Дуглас М. (1994) Риск как судебный механизм. Thesis, (5): 242-276.

ИA REGNUM (2019) Сюжет «Экотехнопарк "Шиес" в Архангельской области». Доступно по ссылке: https://regnum.ru/news/dossier/6574.html (дата обращения: 15 августа 2019).

Каширских О.Н. (2012) Публичная сфера и легитимность персоналистской системы власти в России. Вестник общественного мнения. Данные. Анализ. Дискуссии, 112 (2): $63-72$.

Кертман Г.Л. (2000) Катастрофизм в контексте российской политической культуры. Полис. Политические исследования, (4): 6-18.

Крючкова И. (2018) Губернатора в отставку. Доступно по ссылке: https://www.znak. com/2018-12-03/30 tysyach_zhiteley_severa_vyshli_na_mitingi_protiv_vvoza_othodov_iz moskvy (дата обращения: $1 \overline{4}$ августа 2019).

Кулясов И.П. (2003) Динамика экологического движения: экополитический аспект на примере Вологодского региона. Спектрум: Экология в Северо-западном регионе России: $2-12$.

Ролз Дж. (2010) Теория справедливости. М.: ЛКИ.

Сироткина Е.В., Семенов А. В. (2019) Экономический кризис и оценка эффективности власти: кто несет ответственность за ухудшение уровня жизни в России? Журнал исследований сочиальной политики, 17 (2): 191-206.

Хабермас Ю. (2010) Проблема легитимации позднего капитализма. М.: Праксис.

Яницкий О.Н. (2009) Экосоциология как перспектива. М.К. Горшков (ред.) Россия реформирующаяся. Ежегодник. М.: Институт социологии РАН: 36-57.

Яницкий О.Н. (2011) Экомодернизация России: теория, практика, перспектива. М.: Институт социологии РАН. 
Яницкий О.Н. (2013) Экологические катастрофы: структурно-функииональный анализ. Доступно по ссылке: http://www.isras.ru/publ.html?id=2794 (дата обращения: 14 августа 2019).

Яницкий О.Н. (2017) Отходы как геополитический риск. Власть, (8): 18-23.

Bell A. (1994) Climate of Opinion: Public and Media Discourse on the Global Environment. Discourse \& Society, 5 (1): 33-64.

Blühdorn I., Welsh I. (2007) Eco-politics Beyond the Paradigm of Sustainability: a Conceptual Framework and Research Agenda. Environmental politics, 16 (2): 185-205.

Bullard R. D. (1990) Dumping in Dixie: Race, Class, and Environmental Quality. Boulder, CO: Westview.

Cohen R. (1987) Analyzing the Structure of Argumentative Discourse. Computational linguistics, 13 (1-2): 11-24.

Dobson A. (2012) Green Political Thought. London: Routledge.

Dryzek J. S. (1993) Policy Analysis and Planning: From Science to Argument. In: Fischer F., Forester J. (eds.) The Argumentative Turn in Policy Analysis and Planning. Durham, NC: Duke University Press: 221-240.

Giddens A. (1991) Modernity and Self-identity: Self and Society in the Late Modern Age. Stanford, CA: Stanford University Press.

Giddens A. (1999) Risk and Responsibility. The Modern Law Review, 62 (1): 1-10.

Greene S. A. (2014) Moscow in Movement: Power and Opposition in Putin's Russia. Stanford, CA: Stanford University Press.

Hajer M. A. (1995) The Politics of Environmental Discourse: Ecological Modernization and the Policy Process. Oxford: Clarendon Press.

Jasper J. M. (2018) The Emotions of Protest. Chicago: Chicago University Press.

Latour B. (2011) Politics of Nature: East and West Perspectives. Ethics \& Global Politics, 4 (1): $71-80$.

Lima M. (2004) On the Influence of Risk Perception on Mental Health: Living Near an Incinerator. Journal of Environmental Psychology, 24 (1): 71-84.

Redclift M. (1987) Sustainable Development-Exploring the Contradictions. London: Methuen.

Sjöberg L. (2001a) Limits of Knowledge and the Limited Importance of Trust. Risk Analysis, 21 (1): 189-198.

Sjöberg L. (2001b) Political Decisions and Public Risk Perception. Reliability Engineering and System Safety, 72 (2): 115-123.

Slovic P., Finucane M., Peters E., MacGregor D. (2004) Risk as Analysis and Risk as Feelings: Some Thoughts about Affect, Reason, Risk, and Rationality. Risk Analysis, 24 (2):311-322.

Smyth R., Sobolev A., Soboleva I. (2013) A Well-organized Play: Symbolic Politics and the Effect of the Pro-Putin Rallies. Problems of Post-Communism, 60 (2):24-39.

Stavrakakis Y. (1997) Green Ideology: A Discursive Reading. Journal of Political Ideologies, 2 (3): 259-279.

Sunshine J., Tyler T. R. (2003) The Role of Procedural Justice and Legitimacy in Shaping Public Support for Policing. Law \& Society Review, 37 (3): 513-548.

Thompson J. B. (1995) The Media and Modernity: A Social Theory of the Media. Stanford, CA: Stanford University Press.

Tyler T. R. (1994) Psychological Models of the Justice Motive: Antecedents of Distributive and Procedural Justice. Journal of Personality and Social Psychology, 67 (5): 850-863.

Walker G. (2012) Environmental Justice: Concepts, Evidence and Politics. London: Routledge. 
Kirill Chmel, Aigul Klimova, Evgeniya Mitrokhina

\title{
THE POLITICIZATION OF ENVIRONMENTAL DISCOURSE IN ARKHANGELSK REGION: THE LANDFILL SITE AT SHIES RAILROAD STATION
}

\begin{abstract}
The environmental agenda has proven to be an important factor in political and social protests in Russia across 2018 and 2019. The decision to open a landfill near the Shies station in the Arkhangelsk region strengthened environmental protest throughout Russia, paving the way for discursive changes and actual participation in politics. Nevertheless, the case of the this landfill site cannot be seen an aberration; the state of the environment is not only an object but also a subject of politics in many countries across the world. What makes a social issue take on the features of a political discussion which requires a specific political solution to be made? The aim of this study is to identify the mechanisms behind the politicization of environmental discourse in Russia based on the case of this landfill site in Arkhangelsk region. We will demonstrate how a specific political decision was implemented by the authorities after being made outside of public discussion. The paper will also consider how, among competing discourses, the environmental problem became dominant and then became politicalized among citizens. The empirical basis of the study is 19 semi-structured interviews with residents of the Arkhangelsk region. The research methodology is discourse analysis within the argumentative traction. We will focus solely on argumentative constructions which subjects use to substantiate their position. As a result, in the article we will show that the politicization of discourse and high political mobilization occurred due to three main mechanisms that worked simultaneously: (1) the view that the decision made by the authorities was illegitimate; (2) the view that the whole situation was unfair; and (3) the allocation of blame to certain political actors.
\end{abstract}

Key words: environment, politicization, discourse, landfill for waste disposal, Shies

DOI: $10.17323 / 727-0634-2020-18-1-83-98$

\section{References}

Beck U. (2000) Obschestvo riska: na puti knovomu modernu [A Risk Society: Towards a New Modernity]. Moscow: Progress-Tradiciya.

Kirill Chmel- Bachelor of Arts (BA) in Political Science, Junior Research Fellow, Laboratory for Comparative Social Research, National Research University 'Higher School of Economics', Moscow, Russian Federation. Email: kchmel@hse.ru

Aigul Klimova- PhD (Kandidat Nauk) in Sociology, Associate Professor, Department of Sociology; Senior Research Fellow, Laboratory for Comparative Social Research, National Research University ‘Higher School of Economics', Moscow, Russian Federation. Email: amavletova@hse.ru

Evgeniya Mitrokhina- PhD student, Doctoral School of Political Science, Research Assistant, Laboratory for Comparative Social Research, National Research University 'Higher School of Economics’, Moscow, Russian Federation. Email: emitrokhina@hse.ru 
Bell A. (1994) Climate of Opinion: Public and Media Discourse on the Global Environment. Discourse \& Society, 5 (1):33-64.

Blühdorn I., Welsh I. (2007) Eco-politics Beyond the Paradigm of Sustainability: a Conceptual Framework and Research Agenda. Environmental politics, 16 (2): 185-205.

Bullard R. D. (1990) Dumping in Dixie: Race, Class, and Environmental Quality. Boulder, CO: Westview.

Cohen R. (1987) Analyzing the Structure of Argumentative Discourse. Computational Linguistics, 13 (1-2): 11-24.

Dobson A. (2012) Green Political Thought. London: Routledge.

Dryzek J. S. (1993) Policy Analysis and Planning: From Science to Argument. In: Fischer F., Forester J. (eds) The Argumentative Turn in Policy Analysis and Planning. Durham, NC: Duke University Press: 221-240.

Douglas M. (1994) Risk kak sudebniy mekhanizm [Risk as a Forensic Resource]. Thesis, (5): $242-276$.

Giddens A. (1991) Modernity and Self-identity: Self and Society in the Late Modern Age. Stanford, CA: Stanford University Press.

Giddens A. (1999) Risk and Responsibility. The Modern Law Review, 62 (1): 1-10.

Greene S. A. (2014) Moscow in Movement: Power and Opposition in Putin's Russia. Stanford, CA: Stanford University Press.

Habermas J. (2010) Problema legitimacii pozdnego kapitalizma [Legitimation Problems in Late Capitalism]. Moscow: Praksis.

Hajer M. A. (1995) The Politics of Environmental Discourse: Ecological Modernization and the Policy Process. Oxford: Clarendon Press.

IA REGNUM (2019) Syuzhet 'Ekotekhnopark "Shies" v Arkhangel'skoy oblasti' [The Report of the EcoTechnoPark in Shies, Arkhangelsk Region]. Available at: https://regnum.ru/news/ dossier/6574.html (accessed 14 August 2019).

Jasper J. M. (2018) The Emotions of Protest. Chicago: Chicago University Press.

Kashirskih O. N. (2012) Publichnaya sfera i legitimnost' personalistskoy sistemy vlasti v Rossii [The Public Sphere and the Legitimacy of the Personalistic System of Power in Russia]. Vestnik obshhestvennogo mneniya. Dannye. Analiz. Diskussii [Bulletin of Public Opinion. Data. Analysis. Discussions], 112 (2): 63-72.

Kertman G.L. (2000) Katastrofizm v kontekste rossiyskoy politicheskoy kul'tury [Catastrophism in the Context of the Russian Political Culture.]. Polis. Politicheskie issledovaniya [Polis. Political Studies], (4): 6-18.

Kruchkova I. (2018) Gubernatora v otstavku [The Governor Should Resign]. Available at: https://www.znak.com/2018-12-03/30_tysyach_zhiteley_severa_vyshli_na_mitingi_protiv_ vvoza_othodov_iz_moskvy (accessed 14 August 2019).

Kulyasov I.P. (2003) Dinamika ekologicheskogo dvizheniya: ekopoliticheskiy aspekt na primere Vologodskogo regiona [The Dynamics of the Ecological Movement: the Ecological-Political Aspect of the Vologda Region Case]. Spektrum: Ekologiya v Severo-zapadnom regione Rossii [Spectrum: Ecology in the North-Western Region of Russia]: 2-12.

Latour B. (2011) Politics of Nature: East and West Perspectives. Ethics \& Global Politics, 4 (1): $71-80$.

Lima M. (2004) On the Influence of Risk Perception on Mental Health: Living Near an Incinerator. Journal of Environmental Psychology, 24 (1): 71-84. 
Rawls J. (2010) Teoriya spravedlivosti [Theory of Justice]. Moscow: LKI.

Redclift M. (1987) Sustainable Development-Exploring the Contradictions. London: Methuen.

Sjöberg L. (2001 a) Limits of Knowledge and the Limited Importance of Trust. Risk Analysis, 21 (1): 189-198.

Sjöberg L. (2001 b) Political Decisions and Public Risk Perception. Reliability Engineering and System Safety, 72 (2): 115-123.

Slovic P., Finucane M., Peters E., MacGregor D. (2004) Risk as Analysis and Risk as Feelings: Some Thoughts about Affect, Reason, Risk, and Rationality. Risk Analysis, 24 (2): 311--322.

Smyth R., Sobolev A., Soboleva I. (2013) A Well-organized Play: Symbolic Politics and the Effect of the Pro-Putin Rallies. Problems of Post-Communism, 60 (2):24-39.

Sirotkina E. V., Semenov A. V. (2019) Economic Crisis and the Assessment of Public Effectiveness: Who Bears Responsibility for the Economic Downturn in Russia? The Journal of Social Policy Studies, 17(2): 191-206.

Stavrakakis Y. (1997) Green Ideology: A Discursive Reading. Journal of Political Ideologies, 2 (3): 259-279.

Sunshine J., Tyler T. R. (2003) The Role of Procedural Justice and Legitimacy in Shaping Public Support for Policing. Law \& Society Review, 37 (3): 513-548.

Thompson J. B. (1995) The Media and Modernity: A Social Theory of the Media. Stanford, CA: Stanford University Press.

Tyler T. R. (1994) Psychological Models of the Justice Motive: Antecedents of Distributive and Procedural Justice. Journal of Personality and Social Psychology, 67 (5): 850-863.

Vinogradova A. (2019) Sovsem zazhralis': kto v Rossii ne ljubit moskvichej [They Got Stuck Completely: Who in Russia Does Not Like Muscovites]. Available at: https://www.gazeta.ru/ lifestyle/style/2019/05/a_12385219.shtml (accessed 05 July 2019).

Vorobyov D. (1999) Kampanii po zashchite karel'skih lesov: mobilizaciya resursov [Campaigns for the Protection of Karelian Forests: Resource Mobilization]. In: E. Zdravomyslova, M. Tysyachnyuk (eds.) Ekologicheskoe dvizhenie v Rossii. Sb. nauchn. Statej [Ecological Movement in Russia. Collection of Scientific Articles]. St. Petersburg: CISR:72-87.

Walker G. (2012) Environmental Justice: Concepts, Evidence and Politics. London and New York: Routledge.

Yanitsky O. N. (2009) Ekosotsiologiya kak perspektiva [Ecosociology as a Perspective]. In: M.K. Gorshkov. (ed.) Rossiya reformiruyushchayasya. Ezhegodnik [Russia is Reforming. Yearbook]. Moscow: Institut sotsiologii RAN:36-57.

Yanitsky O. N. (2011) Ekomodernizatsiya Rossii: teoriya, praktika, perspektiva [Eco-modernization of Russia: Theory, Practice, Prospective]. Moscow: Institut sotsiologii RAN.

Yanitsky O. N. (2013) Ekologicheskie katastrofy: strukturno-funktsional'nyy analiz [Environmental Disasters: Structural and Functional Analysis]. Available at: http://www.isras.ru/publ. html?id=2794 (accessed 15 August 2019).

Yanitsky O.N. (2017) Otkhody kak geopoliticheskiy risk [Waste as a Geopolitical Risk]. Vlast' [Power], (8): 18-23. 